EPRA International Journal of Economic and Business Review-Peer Reviewed Journal Volume - 10, Issue - 2, February 2022 | e-ISSN: 2347 - 9671| p- ISSN: 2349 - 0187

\title{
HRM ROLES IN PROMOTING FINANCIAL INCLUSION IN INDIAN BANKING SECTOR: AS AN EMPIRICAL STUDY IN CO-OPERATIVE BANKS
}

\author{
Dr. Moath Mahmoud Alshar ${ }^{1}$, Dr. M. Sathya Shivalini ${ }^{2}$ \\ Business Management/ Osmania University, India
}

The main aim of the current study is to identify the importance of human resource management department in providing the technology (Use of Biometric Machine by BC/BF/Bank Mitr, Use of Mobile/Internet Banking, sending SMS after every transaction and Fixing Automatic Cash Depositing Machine/Passbook Printing Machine) for promoting the financial inclusion in Co-operative banking sector. The employees with reference to the importance of human resource management in the Cooperative banking sector represented by the five cooperative branches are considered in this paper. The study population consisted of all employees in Co-operative banking sector. A questionnaire was drafted and presented to the one hundred and fifty employees randomly selected from the list of employees working for these banks. From one hundred and fifty employees, fifty employees properly filled the questionnaires and this is taken as the main source of data for the study. To achieve the study objectives, "To investigate into the relationship between Age, Gender and Educational level (demographic variable) of the employees and the impact of HRM technology channels on financial inclusion promotion".

The researcher used descriptive-analytical methods. The data was analyzed by employing a One-way ANOVA test at 5\% level of significance using SPSS statistical software. The result showed that 'the banks employees strongly confirmed the technology provided by HRM department for promoting the financial inclusion'”.
\end{abstract}

KEYWORDS: Human Resource Management (HRM), Financial Inclusion, Indian banking sector.

\section{INTRODUCTION}

HRM is important for bankers because banking is a service industry. Management of people and management of risk are two key challenges faced by bankers. Efficient risk management may not be possible without an efficient and selected workforce. Banking has been and will always be a "people's business". Banks must articulate and emphasize the core values to attract and retain customers. There is a significant relationship between employees of the cooperative banks and productivity with HR practices, selection, employee benefits, compensation training, and staffing practices. This implies that banks cannot simply improve the quality of their human resource by spending only on recruiting employees or changes in bank structure or establishing new branches.

The management must focus on training the firm's human resources for a long time commitment. The contribution of human resources depends on various factors like education qualification of employees, organizational environment, Bank policies, and other 
factors. It is fact that, if employees are educated on financial matters it supports the values of organization transparency in bringing development in financial matters and of the organization. A study stated that designing and implementing effective training and development systems is a particular challenge because, "all the costs are borne in the present, while all the benefits will accrue in the future". With the significant increase in the complexity and magnitude of banking services especially with a view of the task undertaken by the co-operative banks for the socio-economic development in urban, semi-urban, and rural areas, the need for the training has been felt important for developing financial inclusion.

This article proposes a reflection of both research opportunities and on the management challenges of cooperative banks with particular employees on human resource management issues.

The current study focuses on the pivotal role that, "human resources management can play in promoting and enhancing financial inclusion through bank employees". This is based on the importance of the organization's human resources for innovation and development to reach the highest level of effectiveness and effectiveness.

\section{HUMAN RESOURCE} MANAGEMENT (HRM)

Is the method of the usage of people, teaching them, compensating them, developing insurance policies referring to them, and developing methods to maintain them. As a field, HRM has gone through many adjustments over the closing twenty years, giving it an even higher quintessential function in today's organizations. In the past, HRM supposed processing payroll, sending birthday objects to employees, arranging organization outings, and making sure types have been stuffed out correctlyin different words, higher of an administrative function as a choice than a strategic feature critical to the success of the organization.

\section{THE ROLES OF HRM}

Keep in the idea that many aspects of HRM are moreover responsibilities exclusive department managers perform, which is what makes these statistics important, despite the occupation route taken. Most specialists agree on seven main roles that HRM performs in organizations. One of the most critical features is the Development of Workplace Policies. Every commercial enterprise company has insurance policies to make certain fairness and continuity interior the organization.

One of the jobs of HRM is to enhance the verbiage surrounding these policies. In the enhancement of policies, HRM, management, and executives are involved in the process. For example, the HRM specialist will possibly apprehend the choice for insurance or an alternate of policy, are looking for opinions on the policy, write the policy, and then talk that insurance to employees. It is key to phrase proper right here that HR departments do now not and cannot work alone. Everything they do needs to include all one of kind departments in the organization.

The human resource management department encourages and promoting financial inclusion by teaching bank employees whom they deal with technology options like (Use of Biometric Machine by BC/BF/Bank Mitr, Use of Mobile/Internet Banking, sending SMS after every transaction and Fixing Automatic Cash Depositing Machine/Passbook Printing Machine. Etc.

\section{FINANCIAL INCLUSION}

Financial Inclusion (FI) ability extends the attain of the financial sector to weaker sections of the society as nicely as geographical areas that have been ignored in the past. Financial Inclusion rests on three pillars viz. get admission to financial services, affordability and proper utilization of banking services. Financial inclusion can be accomplished solely if all three pillars exhibit affirmative results. It refers to a scenario the place human beings come upon difficulties in having access to or the use of monetary offerings and merchandise in the mainstream that are terrific to their needs, which allow them to lead a regular life. The poor, socially underprivileged, disabled, senior residents as nicely as children, women, and uneducated, ethnic minorities and unemployed are financially excluded in India. For the inclusive and built-in boom method of any economy, the central bank of India performs a key position in accomplishing the aim of monetary inclusion. Reserve Bank of India (RBI) describes monetary inclusion as 'the manner of making sure get admission to fabulous financial merchandise and offerings wished via all sections of the society in prevalent and prone companies such as weaker sections and low-income agencies at a low-cost cost, pretty and transparently.

The fundamental intention of financial inclusion is to furnish the formal monetary market and to defend them from the casual savings market so that they can be delivered into the mainstream of financial inclusion.

\section{LITERATURE REVIEW}

Abdul Azeez, N. P., \& Akhtar, S. J. (2021). The financial service companies and policymakers have engaged with this assignment by way of in search of insights into the socio, economic, demographic and cultural elements that instantaneous humans to be conscious and analyze about financial offerings and products, strive them out, and use them over time. The determinants of monetary literacy focal point extra sharply on the socio-economic demographic factors, and have used everyday least square, more than one regression model. This mannequin 
determines how several unbiased variables particularly age; gender, income, religion, social groups, family size, marital status, instructional level, occupation, etc. notably affect the monetary literacy of the respondents. Biswas, S., \& Gupta, A. (2021). The learn about assesses the popularity of financial Inclusion in West Bengal and finds it affects household decision-making of 600 respondents from eight chosen districts of the state. The financial literacy of girls and rural respondents is discovered to be lower. Higher earnings and education stay the different sizable determinants of monetary literacy. Financial literacy is located to notably have an effect on saving decision, funding decision, borrowing propensity and borrowing quality, the first three being positively and fourth being negatively influenced via monetary literacy. However, on retirement planning, no sizeable effect is observed. Sibi, M. S. (2021, March). The important motive of this study is to set up the mediating position of financial intermediaries in the relationship between monetary literacy and financial inclusion of the bad in creating international locations with records from rural Uganda. The facts for this find out about had been analyzed the use of Partial Least Square (PLS). The outcomes published that financial intermediaries notably mediates the relationship between financial literacy and financial inclusion. The presence of monetary intermediaries such as microfinance banks beautifies monetary literacy to amplify the scope of monetary inclusion of the negative in rural Uganda. Thus, coverage makers and advocates of monetary literacy, mainly in creating nations need to use monetary intermediaries such as microfinance banks to roll out monetary literacy programs. This can be executed via the provision of financial literacy clinics, workshops and seminars the place the terrible can analyze private finance the usage of a hands-on approach. This will assist them to make sensible financial selections and preferences closer to consumption of complicated monetary merchandise supplied utilizing the rural-based financial institutions. Mani, M. (2021). Financial literacy is the ability to handle the hassle of financial exclusion. It is a mixture of awareness, skills, knowledge, mindset and behaviours critical to making sound financial choices and attaining monetary nicely-being. The objective of this learn about is to analyze present-day policy, practices and pieces of evidence on financial literacy. The find out about has been carried out on the groundwork of evaluating of literature and secondary facts amassed from a variety of sources. It is discovered that the authorities of India, RBI and different regulatory bodies are jogging economic literacy campaigns thru various mediums. Financial literacy centers (FLCs) are contributing to the enhancement of monetary literacy. However, they want to be reinforced by way of improving resources. Inclusion of financial training in faculty and university curriculum has additionally been recommended. Scope of the find out about is constrained to Ghaziabad district of Uttar Pradesh in India. The find out about would possibly be precious for policymakers in bettering monetary inclusion. Alshar', M M \& Shivalini M. S. (2022). The main objective of the current paper is to identify the important roles of human resource management in promoting financial inclusion in the Indian banking sector. The employees with reference to the roles of human resource management in the Indian banking sector represented by the five banks is studied in this paper. The study population consisted of all employees in five Indian banks. A questionnaire was drafted and mailed to the one hundred and fifty employees randomly selected from the list of employees working for those banks. Fifty of the one hundred and fifty employees properly filled the questionnaires and this is the main data source for my study. To achieve the objectives of the study, "to investigate into any relationship between Age, Gender and Educational level (demographic variable) of the employees and their impact on financial inclusion promotion due to HRM roles" the researcher used descriptive-analytical methods. The data was analyzed by employing a One-way ANOVA test at 5\% level of significance using SPSS statistical software. The result showed that the Indian banks' employees strongly conformed to the roles of human resource management in enhancing financial inclusion.

\section{STUDY OBJECTIVES}

The study objective is to identify the human resource management department roles in promoting financial inclusion. Also to what extent does the HRM department play vital roles in enhancing and promoting financial inclusion.

\section{STUDY HYPOTHESIS}

Based on theoretical background and review of previous literature, conceptual models were developed to show the impact of human resource management department roles on financial inclusion.

1. There is no association level between the Age group of banks employees and the technology provided by the HRM department on financial inclusion.

2. There is no effective relationship between the Gender of banks employees and the technology provided by the HRM department on financial inclusion.

3. There is no significant level between the Educational Qualification of banks employees and the technology provided by the HRM department on financial inclusion. 
VIII. JUSTIFICATION OF SELECTING THE QUANTITATIVE RESEARCH

The quantitative approach is provided with suitable research data collection strategy, allowing the collecting of big data from a huge population. The Cronbach' Alpha coefficient is above 0.94 (high reliability). This indicates that each item is internally consistent and hence indicates a high degree of reliability.

\section{JUSTIFICATION OF SELECTION THE QUESTIONNAIRE}

The questionnaire commenced with a brief description of the means of the essential concepts, and it gave guidelines on how to reply to every part of the questionnaire. A preliminary draft used to be developed based totally on a sizeable literature review. It consists of many questions that are consistent with the research aims. For that reason, the research survey may want to be described as being comprehensive. It is divided into two parts. The first section consists of personal information of the respondents such as gender, Age, Educational qualifications area of profession. The second section consists of questions associated with financial inclusion and HRM department roles.

\section{SAMPLE SIZE}

The sample survey covered five branches of cooperative banks. One hundred questionnaires were sent to the five branches.50 questionnaires were returned. Fifty of these were found to be properly filled and had complete information and hence they are considered for my study.

\section{DATA ANALYSIS AND RESULT}

This sample of fifty respondents contains 32 male and 18 female respondents which make up 64 and 36 percent respectively. The largest group of respondents is $(66 \%)$ with Bachelor degree the smallest group of respondents (5\%) with up to secondary. $36 \%$ of the respondents are with (31-40) of age group while $8 \%$ more than fifty years of old leaving the remaining into other smaller years of Age group. This demographic data are detailed as below.

\begin{tabular}{|l|c|c|c|}
\hline Description & Variable & Frequency & Percentage \\
\hline \multirow{3}{*}{ Gender } & Male & 32 & $64 \%$ \\
\hline \multirow{3}{*}{ Educational level } & Female & 18 & $36 \%$ \\
\cline { 2 - 4 } & Up to secondary & 5 & $10 \%$ \\
\cline { 2 - 4 } Age Group & Up to senior secondary & 12 & $12 \%$ \\
\cline { 2 - 4 } & Bachelor & 33 & $66 \%$ \\
\cline { 2 - 4 } & $20-30$ years & 14 & $28 \%$ \\
\cline { 2 - 4 } & $31-40$ years & 18 & $28 \%$ \\
\cline { 2 - 4 } & Above 50 years & 14 & $8 \%$ \\
\hline
\end{tabular}

Based on the objectives and hypotheses of the study, the researchers applied the one way ANOVA at 5\% level of significance to test the association between the role of HRM and financial inclusion promoting. The hypothesizes to be tested are as below.

-H1 stat that, "There is no association level between Age group of banks employees and the technology provided by HRM department on financial inclusion'".

ANOVA Test

\begin{tabular}{|c|c|c|c|c|c|c|}
\hline & & $\begin{array}{c}\text { Sum of } \\
\text { Squares }\end{array}$ & df & $\begin{array}{c}\text { Mean } \\
\text { Square }\end{array}$ & $\mathbf{F}$ & Sig. \\
\hline \multirow{3}{*}{$\begin{array}{l}\text { Technology options used most } \\
\text { for promoting financial } \\
\text { inclusion }\end{array}$} & \multirow{3}{*}{$\begin{array}{c}\text { Between } \\
\text { Groups } \\
\text { Within } \\
\text { Groups } \\
\text { Total }\end{array}$} & .710 & 3 & .237 & 1.579 & .207 \\
\hline & & 6.897 & 46 & .150 & & \\
\hline & & 7.607 & 49 & & & \\
\hline
\end{tabular}

A one-way ANOVA at a five percent level of significance is conducted to test the hypothesis. The P-value of 0.207 , which is greater than 0.05 and hence null hypothesis is accepted. The ANOVA test proved that "There is no association level between Age group of banks employees and the technology provided by HRM department on financial inclusion. This enables me to conclude that, " the banks employees in a different age group have not confirmed the technology provided by HRM department for promoting the financial inclusion".

-H2 states, "There is no effective relationship between Gender of banks employees and the technology provided by HRM department on financial inclusion. 


\begin{tabular}{|c|c|c|c|c|c|c|}
\hline \multicolumn{7}{|c|}{ ANOVA Test } \\
\hline & & $\begin{array}{c}\text { Sum of } \\
\text { Squares }\end{array}$ & df & $\begin{array}{c}\text { Mean } \\
\text { Square }\end{array}$ & $\mathbf{F}$ & Sig. \\
\hline \multirow{3}{*}{$\begin{array}{l}\text { Technology options used most } \\
\text { for promoting financial } \\
\text { inclusion }\end{array}$} & \multirow{3}{*}{$\begin{array}{c}\text { Between } \\
\text { Groups } \\
\text { Within } \\
\text { Groups } \\
\text { Total }\end{array}$} & .068 & 1 & .068 & .436 & .012 \\
\hline & & 7.539 & 48 & .157 & & \\
\hline & & 7.607 & 49 & & & \\
\hline
\end{tabular}

A one-way ANOVA at a five percent level of significance is conducted to test the hypothesis. The $\mathrm{P}$-value of 0.012 , which is less than 0.05 and hence null hypothesis is rejected. The ANOVA test proved that "There is an effective relationship between the Gender of banks employees and the technology provided by HRM department on financial inclusion"'. This enables me to conclude that, " the banks employees in different Gender confirmed the technology provided by HRM department for promoting the financial inclusion'.

-H3 state that, "'There is no significant level between Educational Qualification of banks employees and the technology provided by HRM department on financial inclusion",

\begin{tabular}{|c|c|c|c|c|c|c|}
\hline \multicolumn{7}{|c|}{ ANOVA Test } \\
\hline & & $\begin{array}{c}\text { Sum of } \\
\text { Squares }\end{array}$ & $\mathbf{d f}$ & $\begin{array}{c}\text { Mean } \\
\text { Square }\end{array}$ & $\mathbf{F}$ & Sig. \\
\hline \multirow{3}{*}{$\begin{array}{l}\text { Technology options used most } \\
\text { for promoting financial } \\
\text { inclusion }\end{array}$} & $\begin{array}{c}\text { Between } \\
\text { Groups }\end{array}$ & .358 & 2 & .179 & 1.160 & .042 \\
\hline & $\begin{array}{l}\text { Within } \\
\text { Groups }\end{array}$ & 7.249 & 47 & .154 & & \\
\hline & Total & 7.607 & 49 & & & \\
\hline
\end{tabular}

A one-way ANOVA at a five percent level of significance is conducted to test the hypothesis. The P-value of 0.042 , which is less than 0.05 and hence null hypothesis is rejected. The ANOVA test proved that "There is an effective relationship between Educational Qualification level of banks employees and the technology provided by HRM department on financial inclusion', This enables me to conclude that, " the banks employees in different Educational Qualification confirmed the technology provided by HRM department for promoting the financial inclusion',

\section{SUGGESTIONS AND CONCLUSIONS}

This paper aims to build a more complete framework of the factors, which influence the promoting of financial inclusion in the Indian banking sector. The results of this study clearly show that "the cooperative bank employees strongly confirmed the technology provided by HRM department for enhancing and promoting the financial inclusion".

This research contributes to the understanding of the HRM department roles and Financial Inclusion. It describes the integration of the human resource management department and its roles in promoting financial inclusion. I hope that these conclusions will shed some mild for top management and permit them to make bigger interest in the practices of human resource management due to the fact of their significance in encourage employee's overall performance in the co-operative banking sector.

It is suggested that, if the institution grants adequate training and development chances their bank staff are better satisfied, and employees are specially trained in educating people concerning special advantages of the schemes of banks. Word of mouth propagation of the schemes is very important and this should emphasize. A little effort in pushing the schemes further will in all probability reach the shores of success in developing financial inclusion. In addition, the management should highlight and promote the new concept of human resources management, called Electronic human resources management and practices. The aim is to develop all the departments of the bank in an efficient and effective manner.

\section{REFERENCE}

1. Mani, M. (2021). Financial Inclusion through Financial Literacy: Evidence, Policies, and Practices. International Journal of Social Ecology and Sustainable Development (IJSESD), 13(1), 1-12.

2. Sibi, M. S. (2021, March). Intelligent Statistical Modeling and Approaches of Financial Literacy. In 2021 7th International Conference on Advanced Computing and Communication Systems (ICACCS) (Vol. 1, pp. 1685-1689). IEEE.

3. Biswas, S., \& Gupta, A. (2021). Impact of Financial Literacy on Household DecisionMaking: A Study in the State of West Bengal in 
India. International Journal of Economics and Financial Issues, 11(5), 104-113.

4. Abdul Azeez, N. P., \& Akhtar, S. J. (2021). Determinants of financial literacy in rural India: A study of Aligarh district. International Journal of Financial Engineering, 2150009.

5. Alshar', $M M$ \& Shivalini M. S. (2022). The role of HRM in enhancing financial inclusion in India Banking Sector. EPRA International Journal of Economics, Business and Management Studies (EBMS). (2347-4378), DOI No: 10.36713/epra9442.

6. Shafi, M., \& Medabesh, A. H. (2012). Financial inclusion in developing countries: Evidences from an Indian State. International Business Research, 5(8), 116.

7. Sarma, M., \& Pais, J. (2011). Financial inclusion and development. Journal of international development, 23(5), 613-628.

8. Goel, S., \& Sharma, R. (2017). Developing a financial inclusion index for India. Procedia computer science, 122, 949-956.

9. Arora, R. U. (2012). Financial inclusion and human capital in developing Asia: The Australian connection. Third World Quarterly, 33(1), 177-197.

10. Gretta, S. A. A. B. (2017). Financial inclusion and growth. The Business \& Management Review, 8(4), 434.

11. https://www.worldbank.org/en/topic/financialincl usion

12. https://www.business-standard.com/about/whatis-financial-inclusion 